\title{
A Panchromatic Boradiazaindacene (BODIPY) Sensitizer for Dye-Sensitized Solar Cells
}

2008

Vol. 10, No. 15

3299-3302

\section{Sule Erten-Ela, ${ }^{\dagger}$ M. Deniz Yilmaz, ${ }^{\ddagger}$ Burcak Icli, ${ }^{\ddagger}$ Yavuz Dede, ${ }^{\ddagger}$ Siddik Icli, ${ }^{\dagger}$ and Engin U. Akkaya ${ }^{*, \S}$}

Solar Energy Institute, Ege University, Izmir, Turkey TR-35100, Department of

Chemistry, Middle East Technical University, Ankara, Turkey TR-06531, and

Department of Chemistry and UNAM-Institute of Materials Science and

Nanotechnology, Bilkent University, Ankara, Turkey TR-06800

eua@fen.bilkent.edu.tr

Received May 21, 2008

\section{ABSTRACT}

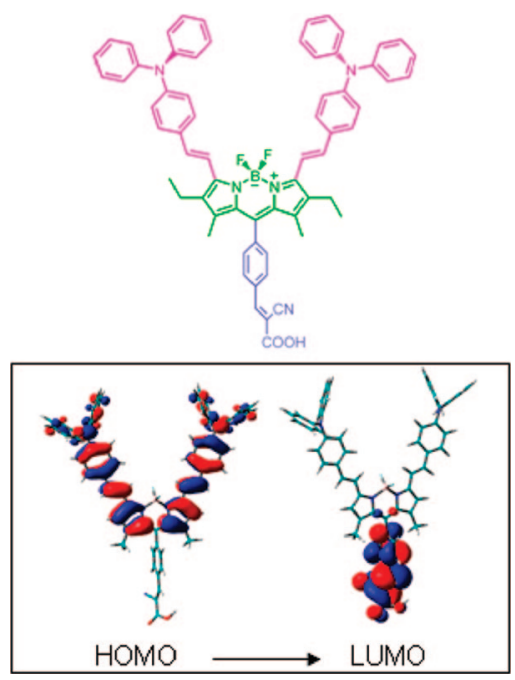

A novel distyryl-substituted boradiazaindacene (BODIPY) dye displays interesting properties as a sensitizer in DSSC systems, opening the way to further exploration of structure-efficiency correlation within this class of dyes.

Among environment friendly and renewable sources of energy, solar cells have always been high on the list of likely candidates. Unfortunately, large-scale commercialization is hampered by the production costs. Dye-sensitized solar cells ${ }^{1}$ (DSSCs) appear to be highly promising alternatives to more expensive solar cell technologies. Considering the current

\footnotetext{
Ege University.

Middle East Technical University.

$\S$ Bilkent University.

(1) (a) Oregan, B.; Gratzel, M. Nature 1991, 353, 737-740. (b) Hagfeldt,
} A.; Gratzel, M Acc. Chem. Res. 2000, 33, 269-277. maximal level of overall conversion efficiency $(\eta)$ under simulated sunlight for DSSCs $(11 \%){ }^{2}$ improvements in efficiency and durability would certainly facilitate widespread utilization of this technology.

It is clear that there are a number of factors determining the efficiency of solar cells, but the structural and physical properties of the sensitizer are clearly important ones. As a result, many laboratories around the world have active

(2) Nazeeruddin, M. K.; De Angelis, F.; Fantacci, S.; Selloni, A.; Viscardi, G.; Liska, P.; Ito, S.; Bessho, T.; Gratzel, M. J. Am. Chem. Soc. 2005, 127, 16835-16847. 
research programs in optimizing the dye component of the DSSCs. Ruthenium dyes, while holding the record for conversion efficiencies, have relatively low extinction coefficients, and they are also considered to be expensive and hard to purify. Motivated by the possibility of finding a replacement for metal-complex dyes, a number of chromophores, including coumarins, ${ }^{3}$ indolines, ${ }^{4}$ oligoenes, ${ }^{5}$ merocyanines, ${ }^{6}$ hemicyanines, ${ }^{7}$ oligothiophenes, ${ }^{8}$ functionalized thiophenes, ${ }^{9}$ squaraines,${ }^{10}$ benzothiadiazoles, ${ }^{11}$ perylenetetracarboxylic acid derivatives, ${ }^{12}$ diphenylaminostyrenes, ${ }^{13}$ and phthalocyanines, ${ }^{14}$ have been studied, with varying degrees of success. For the most efficient of these sensitizers, the overall conversion efficiency is limited to 4-7.5\% (Figure 2).

Boradiazaindacenes (the parent dye, 1), commonly known as BODIPY dyes, have been recognized ${ }^{15}$ as useful fluorescent labels for biomolecules for some time. Within the past decade, there is much renewed interest ${ }^{16}$ in these dyes, due to the development of new avenues for derivatization and novel applications in a highly diverse field, including chemosensors, ${ }^{17}$ logic gates, ${ }^{18}$ light harvesters, ${ }^{19}$ energy transfer casettes, ${ }^{20,21}$ and photodynamic therapy. ${ }^{22}$ It is known that photostability of the BODIPY dyes is signifi-

(3) Hara, K.; Sayama, K.; Ogha, Y.; Shinpo, A.; Suga, S.; Arakawa, H. Chem. Commun. 2001, 569-570.

(4) Horiuchi, T.; Miura, H.; Sumioka, K.; Uchida, S. J. Am. Chem. Soc. 2004, 126, 12218-12219.

(5) Kitamura, T.; Ikeda, M.; Shigaki, K.; Inoue, T.; Anderson, N. A.; Ai, X.; Lian, T.; Yanagida, S. Chem. Mater. 2004, 16, 1806-1812.

(6) Sayama, K.; Hara, K.; Mori, N.; Satsuki, M.; Suga, S.; Tsukagoshi, S.; Abe, Y.; Sugihara, H.; Arakawa, H. Chem. Commun. 2000, 1173-1174.

(7) Wang, Z.-S.; Li, F.-Y.; Huang, C.-H. Chem. Commun. 2000, 2063 2064.

(8) Koumura, N.; Wang, Z.-S.; Mori, S.; Miyashita, M.; Suzuki, E.; Hara, K. J. Am. Chem. Soc. 2006, 128, 14256-14257.

(9) Hagberg, D. P.; Yum, J.-H.; Lee, H.; De Angelis, F.; Marinado, T.; Karlsson, K. M.; Humphry-Baker, R.; Sun, L.; Hagfeldt, A.; Gratzel, M.; Nazeeruddin, M. K. J. Am. Chem. Soc. 2008, 130, 6259-6266.

(10) (a) Li, C.; Wang, W.; Wang, X.; Zhang, B.; Cao, Y. Chem. Lett. 2005, 35, 554-555. (b) Burke, A.; Schmidt-Mende, L.; Ito, S.; Gratzel, M. Chem. Commun. 2007, 234-236.

(11) Velusamy, M; Thomas, K. R. J.; Lin, J. T.; Hsu, Y.-C.; Ho, K.-C. Org. Lett. 2005, 7, 1899-1902.

(12) Shibano, Y.; Umeyama, T.; Matano, Y.; Imahori, Y. Org. Lett. 2007 9, 1971-1974.

(13) Xu, W.; Peng, B.; Chen, J.; Liang, M.; Cai, F. J. Phys. Chem. C 2008, 112, 874-880.

(14) He, J.; Benko, G.; Korodi, F.; Polivka, T.; Lomoth, R.; Akermark, B.; Sun, L.; Hagfeldt, A.; Sundstrom, V. J. Am. Chem. Soc. 2002, 124 4922-4932.

(15) (a) Treibs, A.; Kreuzer, F. H. Liebigs Ann. Chem. 1968, 718, 208 223. (b) Haugland, R. P. The Handbook-A Guide to Fluorescent Probes and Labeling Technologies, 10th ed.; Invitrogen Corp., 2005.

(16) (a) Ulrich, G.; Ziessel, R.; Harriman, A. Angew. Chem., Int. Ed. 2008, 47, 1184-1201. (b) Ziessel, R. Compt. Rend. Chim. 2007, 10, 622629. (c) Loudet, A.; Burgess, K. Chem. Rev. 2007, 107, 4891-4932.

(17) (a) Coskun, A.; Akkaya, E. U. J. Am. Chem. Soc. 2005, 127, 1046410465. (b) Rurack, K.; Kollmannsberger, M.; Resch-Genger, U.; Daub, J. J. Am. Chem. Soc. 2000, 122, 968-969. (c) Coskun, A.; Akkaya, E. U. J. Am. Chem. Soc. 2006, 128, 14474-14475. (d) Zeng, L.; Miller, E. W.; Pralle, A.; Isacoff, E. Y.; Chang, C. J. J. Am. Chem. Soc. 2006, 128, 10 11.

(18) Coskun, A.; Deniz, E.; Akkaya, E. U. Org. Lett. 2005, 7, 51875189.

(19) (a) Li, F.; Yang, S. I.; Ciringh, Y. Z.; Seth, J.; Martin, C. H.; Singh, D. L.; Kim, D.; Birge, R. R.; Bocian, D. F.; Holten, D.; Lindsey, J. L. J. Am. Chem. Soc. 1998, 120, 10001-10017. (b) Yilmaz, M. D.; Bozdemir, O. A.; Akkaya, E. U. Org. Lett. 2006, 8, 2871-2873.

(20) Ulrich, G.; Goze, C.; Guardigli, M.; Roda, A.; Ziessel, R. Angew. Chem., Int. Ed. 2005, 44, 3694-3698.

(21) Loudet, A.; Bandichhor, R.; Wu, L.; Burgess, K. Tetrahedron 2008, $64,3642-3654$. cantly better ${ }^{23}$ than many sensitizers proposed. One simple derivative of BODIPY was in fact studied ${ }^{24}$ as a sensitizer within the DSSC context, and charge separation was clearly observed; however, very low overall conversion efficiencies were obtained.

We now propose that, when judiciously designed, BODIPY dyes have certain unique features that could make them highly advantageous compared to most other organic dyes, and thus, they are highly promising in this regard. (i) BODIPY dyes have high extinction coefficients (70 000-80 000 $\mathrm{M}^{-1} \mathrm{~cm}^{-1}$ ) and can easily be modified with any desired functionalities. (ii) Absorption peak can be moved to longer wavelengths through simple modifications, keeping strong absorption cross sections. (iii) BODIPY dyes have inherent asymmetry in charge redistribution when they undergo $\mathrm{S}_{0} \rightarrow \mathrm{S}_{1}$ transition upon excitation, increasing the charge density on the meso-carbon (C-8), while decreasing it in most other positions in the boradiazaindacene system (Supporting Information). This inherent directionality of charge redistribution pinpoints $\mathrm{C}-8$ as the optimal position of charge injection. (iv) The directionality observed in excitation can be further enhanced with strategically placed electronwithdrawing and electron-donating groups, and on the basis of earlier work, ${ }^{25}$ cyanoacrylic acid and $4-N, N^{\prime}$-diphenylaminophenyl groups are to be of tremendous utility in this regard.

With these considerations, we designed compound $\mathbf{2}$ (Figure 1). The synthesis is convenient; the BODIPY core

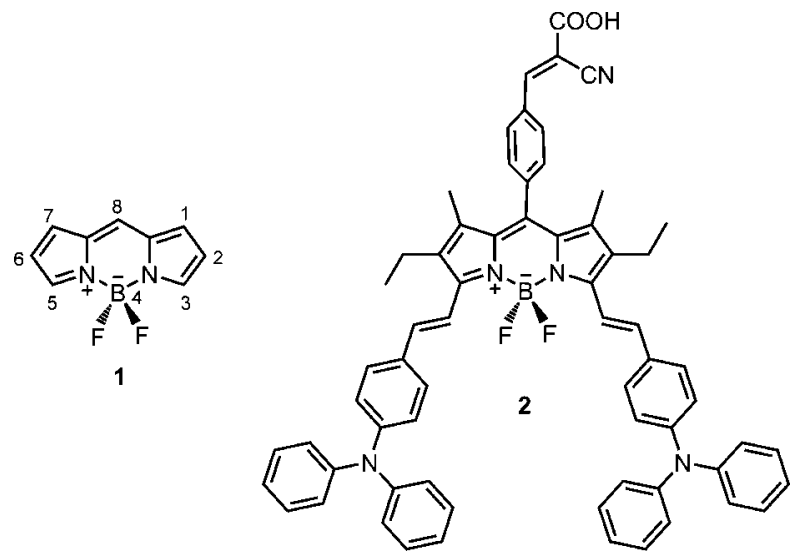

Figure 1. Structure and numbering of the parent boradiazaindacene 1 and the structure of the target sensitizer.

was synthesized using monoprotected terephthaldehyde under standard conditions. The green-emitting dye was then

(22) Atilgan, S.; Ekmekci, Z.; Dogan, A. L.; Guc, D.; Akkaya, E. U. Chem. Commun. 2006, 4398-4400.

(23) Yogo, T.; Urano, Y.; Ishitsuka, Y.; Maniwa, F.; Nagano, T. J. Am. Chem. Soc. 2005, 127, 12162-12163.

(24) Hattori, S.; Ohkubo, K.; Urano, Y.; Sunahara, H.; Nagano, T.; Wada, Y.; Tkachenko, N. V.; Lemmetyinen, H.; Fukuzumi, S. J. Phys. Chem. B 2005, 109, 15368-15375.

(25) Hagberg, D. P.; Edvinson, T.; Marinado, T.; Boschloo, G.; Hagfeldt, Sun, L. Chem. Commun. 2006, 2245-2247. 


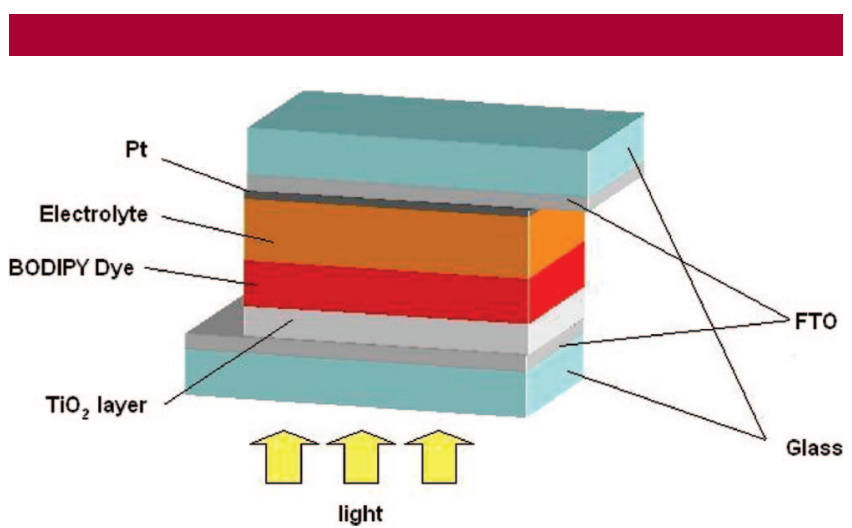

Figure 2. Schematic drawing of a dye-sensitized solar cell: the BODIPY dye is placed under the F-doped $\mathrm{SnO}_{2}$ layer and adsorbed to nanocrystalline $\mathrm{TiO}_{2}$.

condensed with $N, N^{\prime}$-diphenylaminobenzaldehyde (prepared from triphenylamine via Vilsmeier formylation). Following the deprotection of the aldehyde group, it was condensed with cyanoacetic acid to place electron-withdrawing cyano and the anchoring carboxylic acid groups in the desired positions. An important part of the design in this dye is to place the anchor and cyano group at the $\mathrm{C}-8$ position, where the charge moves on excitation; a perfect placement for efficient charge injection.

DFT calculations for the dye 2, at the B3PW91/6$31+\mathrm{G}(\mathrm{d}, \mathrm{p}) / / \mathrm{B} 3 \mathrm{LYP} / 6-31 \mathrm{G}(\mathrm{d})$ level of the theory, support directional movement of charge on excitation (Supporting Information). The HOMO is primarily comprised of $\pi$ framework of the BODIPY and the styryl groups, with significant contributions from $\pi$ electrons of the diphenylamino substituent (Figure 3); whereas the LUMO is very

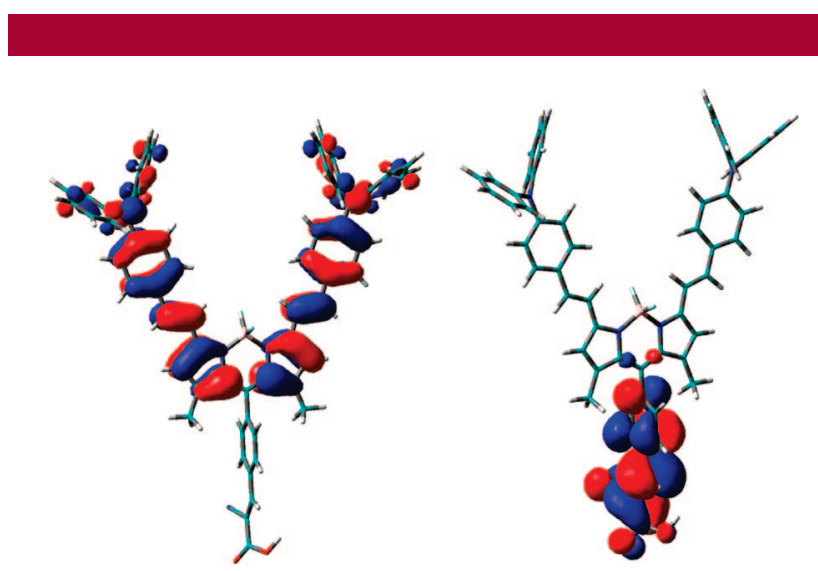

Figure 3. Schematic representation of the frontier orbitals (left, HOMO; right, LUMO) of compound 2 computed at the B3PW91/ $6-31+\mathrm{G}(\mathrm{d}, \mathrm{p}) / / \mathrm{B} 3 \mathrm{LYP} / 6-31 \mathrm{G}(\mathrm{d})$ level of theory. The surfaces are generated with an isovalue at 0.02 .

clearly confined to the $\pi$ system of the anchor group. (See Supporting Information for the nearly identical orbital pictures obtained with other methods.) This overall picture, found at all levels considered, shows a very clear electron density shift from the $\pi$ framework of the BODIPY core and the styryl substituents to the pendant carboxyphenyl moiety upon a vertical excitation of the $\pi-\pi^{*}$ type.

Compound $\mathbf{2}$ has a relatively broad absorption peak at around $700 \mathrm{~nm}$ in chloroform solution, consistent with its charge transfer (ICT) characteristics (Figure 4). The molar

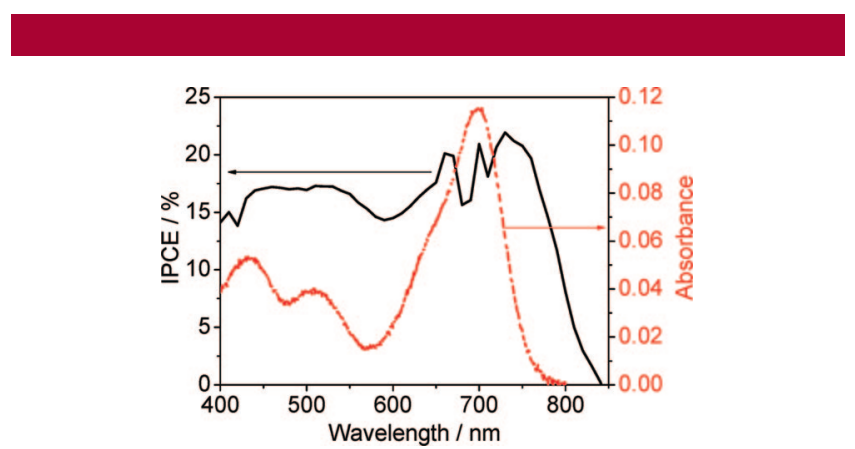

Figure 4. Overlayed absorption spectrum of the dye $\mathbf{2}$ in chloroform (red dashes) and the photocurrent action spectrum (black solid line) obtained under simulated sunlight (AM 1.5). Nearly constant photon-to-current conversion level between 400 and $800 \mathrm{~nm}$ is impressive but, at the same time, an indication of aggregation on the $\mathrm{TiO}_{2}$ surface.

extinction coefficient at the peak wavelength was found to be $69500 \mathrm{M}^{-1} \mathrm{~cm}^{-1}$. Two additional transitions at shorter wavelengths result in a panchromatic performance for this dye. Cyclic voltammetry of the compound 2 (Supporting Information) revealed a HOMO energy level of $5.088 \mathrm{eV}$ and a LUMO energy level of $3.517 \mathrm{eV}$, which is at sufficiently high energy for thermodynamically favorable injection of electrons to nanocrystalline $\mathrm{TiO}_{2}-\mathrm{CB}$. The dyesensitized cell device was constructed in analogy to literature (for experimental details, see the Supporting Information). Characterization of the sandwich type cell (ESI) yielded short-circuit current $\left(J_{\mathrm{SC}}\right)$ of $4.03 \mathrm{~mA} / \mathrm{cm}^{2}$, open-circuit voltage $\left(V_{\mathrm{OC}}\right)$ of $562 \mathrm{mV}$, and fill factor $(\mathrm{FF})$ of $73.5 \%$, giving an $\eta$ of $1.66 \%$. IPCE data (Figure 5) reveal a near constant photon-to-current conversion efficiency with a peak

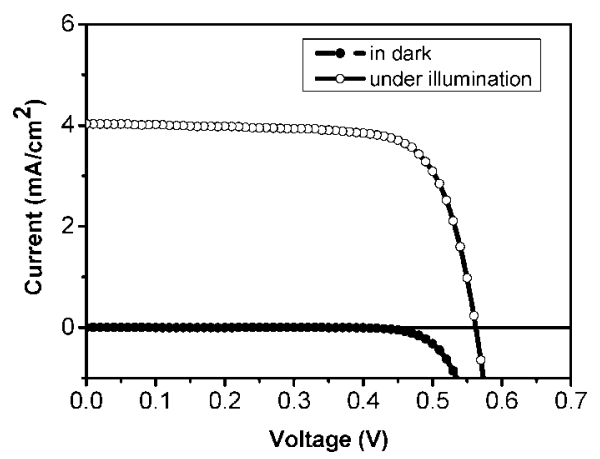

Figure 5. Current versus voltage in the constructed cell. $V_{\mathrm{oc}}=562$ $\mathrm{mV}, J_{\mathrm{sc}}=4.03 \mathrm{~mA} / \mathrm{cm}^{2}, \mathrm{FF}=0.735, \eta=1.66 \%$. Cell's active surface area was $0.159 \mathrm{~cm}^{2}$, and the illumination intensity was 100 $\mathrm{mW} / \mathrm{cm}^{2}$ at $1.5 \mathrm{AM}$ conditions. 
value of $22 \%$ at $750 \mathrm{~nm}$. This peak value, to the best of our knowledge, corresponds to the largest reported monochromatic incident photon-to-current conversion efficiency in the near IR region (i.e., at $750 \mathrm{~nm}$ ) for organic dyes, and second to only a single tris(thiocyanato)terpyridyl-ruthenium complex dye. ${ }^{26}$ In addition, we would like to point out that the reported $\eta$ value was obtained without any of the additives typically used (e.g., cheno; 3a,4a-dihydroxy-5b-cholic acid) for enhancing conversion efficiencies.

In conclusion, we have demonstrated that boradiazaindacenes or BODIPYs can be transformed into satisfactory sensitizers especially in the longer wavelength region of the visible and near-IR region of the solar spectrum. Further

(26) Nazeeruddin, M. K.; Pechy, P.; Renouard, T.; Zakeeruddin, S. M.; Humphry-Baker, R.; Comte, P.; Liska, P.; Cevey, L.; Costa, E.; Shklover, V.; Spiccia, L.; Deacon, G. B.; Bignozzi, C. A.; Gratzel, M. J. Am. Chem. Soc. 2001, 123, 1613-1624. structural optimization reducing the chances of aggregation and enhancing the directionality of charge redistribution in the excited state is very likely to yield more efficient sensitizers. Our work to that end is in progress.

Acknowledgment. The authors gratefully acknowledge valuable advice and guidance provided by Prof. Dr. M. Gratzel and Dr. S. M. Zakeeruddin in EPFL, Switzerland, and State Planning Organization (DPT) and Turkish Academy of Sciences (TUBA) for funding.

Supporting Information Available: Synthesis procedures, computational details, molecular orbital plots, details of cell construction and characterization, and $\mathrm{CV}$ data for the dye. This material is available free of charge via the Internet at http://pubs.acs.org.

OL8010612 